\title{
Timing and nature of the end of the African Humid Period in the Sahel: Insight from pollen data
}

\author{
Kévin Lemonnier \& Anne-Marie Lézine \\ Laboratoire d'Océanographie et du Climat, Expérimentation et Approche \\ Numérique/IPSL, Sorbonne Université, CNRS-IRD-MNHN, Paris, France
}

\begin{abstract}
Pollen, spores, and algae from a $4 \mathrm{~m}$-long sediment core at the Mboro-Baobab site $\left(15^{\circ} 8^{\prime} 58.49^{\prime \prime} \mathrm{N}, 16^{\circ} 54^{\prime} 34.37^{\prime \prime} \mathrm{W}\right)$, in the Niayes region of Senegal were used to provide a record of the end of the African Humid Period (AHP) in the western Sahel. We show that the drying of the Mboro-Baobab landscape was gradual, starting from $3750 \mathrm{cal} \mathrm{yr}$ BP then culminating at $1300 \mathrm{cal}$ yr BP. In contrast, the response of the lake system and the gallery forest developed in two main phases: the sharp decline of tropical humid forest elements at $3200 \mathrm{cal} \mathrm{yr} \mathrm{BP}$ followed by the almost complete collapse of the gallery forests at $2500 \mathrm{cal}$ yr BP. Our results are consistent with those from the central Sahel, which show a gradual transition from the AHP to the modern landscape.
\end{abstract}

\subsection{INTRODUCTION}

At the end of the African Humid Period (AHP), tropical North Africa experienced a major environmental crisis. The southward displacement of the desert margin (Kuper and Kröpelin 2006) with the related loss in biodiversity (Hély et al. 2014; Watrin et al. 2009) along with the decline of wetlands (Lézine et al. 2011) had dramatic consequences for human populations through a decline in population density, cultural adaptations with the development of pastoralism and migrations toward the main rivers (Nile, Senegal, Niger) (Manning and Timpson 2014 and references therein) and the Equatorial forest block (Lézine et al. 2013). How long was this transition from a "green Sahara" to the hyper-arid desert of today? This question remains largely unanswered, as the number of palaeorecords with adequate temporal resolution and age control is low and often contradictory. Based on marine records, deMenocal et al. (2000) showed that an abrupt increase in dust transport to the ocean between 5579 and 5299 cal yr BP marked the end of the AHP in the Saharan desert. Studies in the central Sahara suggested that the modern desert was definitely established at $2700 \mathrm{cal} \mathrm{yr} \mathrm{BP}$ after a period of gradual drying likely originating from the mid-Holocene and intensifying at $4300 \mathrm{cal} \mathrm{yr} \mathrm{BP} \mathrm{(Kröpelin} \mathrm{et} \mathrm{al.} \mathrm{2008;} \mathrm{Lézine} \mathrm{et} \mathrm{al.}$ 2011; Lécuyer et al. 2016).

In the Sahel, interdunal depressions of Senegal and Nigeria provided detailed records of environmental change during the AHP (Lézine 1988; 1989; Salzmann and Waller 1998; Waller et al. 2007). The presence of a water table near the surface favored the development of forest galleries along water bodies. However, pollen studies suggest a contrasted situation: in Senegal, an abrupt change c. 2500 cal yr BP, interpreted as the crossing of a biological threshold, brought about the destruction of the forests and the decline of tropical humid elements (Lézine 1989). 
In Nigeria, the modern vegetation was established earlier, c. 3300 cal yr BP (Salzmann and Waller 1998). However, new data from Jikaryia Lake (Waller et al. 2007) suggest that "rather than a single abrupt event, Late Holocene aridification appears to have occurred progressively" from 4700 cal yr BP onward. Here we present a new and high-resolution pollen record from Mboro-Baobab in the "Niayes" coastal region of Senegal $\left(15^{\circ} 8^{\prime} 58.49^{\prime \prime} \mathrm{N}, 16^{\circ} 54^{\prime} 34.37^{\prime \prime} \mathrm{W}\right)$. We focus on the period between $4300 \mathrm{cal}$ yr BP (the base of the Mboro-Baobab pollen sequence) and the last millennium, which has been the subject of a separate publication (Lézine et al. 2019). Our goal is to determine whether the transition from AHP to the present was abrupt or gradual in this area, to discuss the turnover of species and the response times of forest trees to changes in hydrological conditions.

\subsection{GENERAL SETTING}

Niayes are interdunal depressions with accumulations of organic sediments, formed between linear fixed and partially fixed coastal dune ridges, located along the Atlantic coast between $15^{\circ} \mathrm{N}$ and $16^{\circ} \mathrm{N}$, at roughly $17^{\circ} \mathrm{W}$. The mean annual rainfall $(369 \mathrm{~mm})$ is characteristic of the Sahel, but in response to local soil moisture conditions, the depressions support an array of plant communities that include an azonal extension north of Guinean humid forests and Sudanian dry forests and wooded grasslands (Trochain 1940) (Figure 1A).

The Mboro-Baobab depression is located $2.3 \mathrm{~km}$ from the seashore west of the Mboro paleoriver (Figure 1B), at the edge of the central zone of the Niayes where the sub-surface aquifer is the most developed (Putallaz, 1964). The Mboro-Baobab depression is $570 \mathrm{~m}$ long and $310 \mathrm{~m}$ wide. To the south, it is covered with vegetation and partially exploited for agricultural purposes.
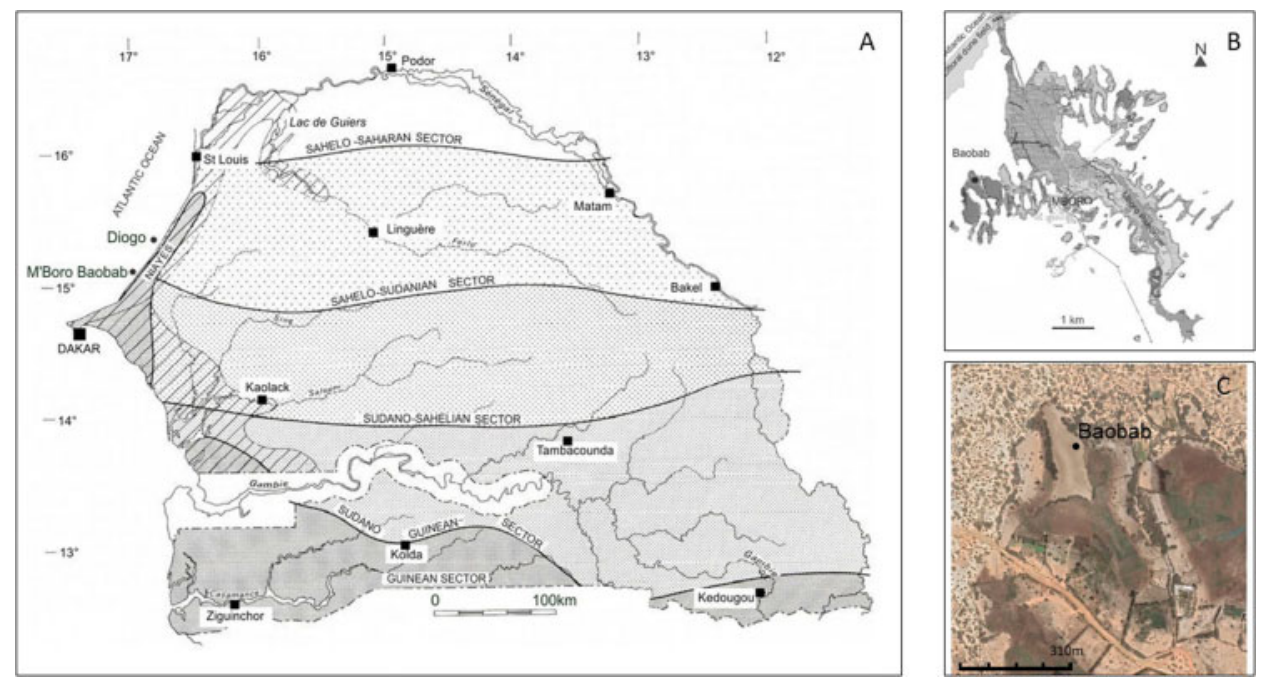

Figure 1. (A) vegetation map of Senegal from Trochain (1940) showing the azonal position of the Niayes along the Atlantic Ocean, north of the Dakar peninsula. Trochain described the vegetation of the Niayes as belonging to a "sub-Guinean domain" owing to its strong relation with the Guinean (rain) forests today found in the Casamance region, south of Senegal. (B) Location map of the Mboro-Baobab interdunal depression west of the Mboro paleoriver channel. In gray, inundated sectors (ORSTOM 1962). (C) Satellite image showing the Mboro- Baobab depression surrounded by dunes fields covered with Sahelian vegetation. The localization of the core in the northern part of the depression is shown. 
Its northern part is an open water basin of $270 \mathrm{~m}$ by $90 \mathrm{~m}$ wide and $0.4 \mathrm{~m}$ maximum depth (Figure 1C). Mboro-Baobab is currently filled by brackish waters and occasionally desiccated.

\subsection{MATERIAL AND METHODS}

A $4 \mathrm{~m}$ long core was collected near the northeastern shore of the open water basin using a manual Russian corer (Jowsey 1966) in 2016 (Lézine et al. 2019). It was divided into 8 sections of 50 $\mathrm{cm}$ each. The sediment consists of homogeneous organic clay. Samples $\left(1 \mathrm{~cm}^{3}\right.$ each $)$ were taken at $5 \mathrm{~cm}$ intervals for pollen and non-pollen palynomorphs (NPP $=$ freshwater algae (Pediastrum, Botryococcus, Coelastrum, Scenedesmus, Tetraedron and undifferentiated fungi) analyses. They were processed using the standard HF method described by Faegri and Iversen (1977). Pollen identification was based on the reference slide and photo collections of the LOCEAN laboratory and the Musée National d'Histoire Naturelle in Paris as well as on pollen atlases of tropical African flora from e.g. Maley (1970), APLF (1974), Ybert (1979) and Bonnefille and Riollet (1980). Pollen nomenclature, which follows the standard defined by the African Pollen Database (Vincens et al. 2007), was based on Lebrun and Stork (1991-2015). The pollen spectra was composed of 105 taxa among which 57 trees, shrubs, lianas and palms, 21 herbs, 16 undifferentiated (trees, shrubs or herbs), 7 aquatics and 4 ferns (Table 1). Pollen taxa have been grouped according to the phytogeographical affinity of the parent plants following Trochain (1940) and White (1983) (Table 1).

Table 1. Mboro-Baobab pollen taxa. A: trees; AL: tree/lianas; L: lianas; I: undifferentiated; N: herbs; Nq: aquatics. Nomenclature from the African Pollen Database. According to Vincens et al. (2007) a "type" is added to the name of the taxon (1) to the genus when several plant genera display similar pollen morphology. The species name can be added in case of monospecificity or when the species is dominant or characteristic in the study area (2) to the species when, the genus being clearly identified, several species can be concerned. SH: Saharan. SL: Sahelian; SU: Sudanian; GU: Guinean.

\begin{tabular}{|c|c|c|c|c|c|c|}
\hline Family & Taxon & $\begin{array}{l}\text { Life } \\
\text { form }\end{array}$ & $\mathrm{SH}$ & SL & SU & $\mathrm{GU}$ \\
\hline \multirow[t]{3}{*}{ ACANTHACEAE } & Hygrophila & $\mathrm{N}$ & & & $\mathrm{x}$ & \\
\hline & Justicia-type & I & & $\mathrm{x}$ & $\mathrm{x}$ & \\
\hline & Justicia-type flava & $\mathrm{N}$ & & $\mathrm{x}$ & $\mathrm{x}$ & \\
\hline \multirow[t]{8}{*}{ AMARANTHACEAE } & Achyranthes-type aspera & $\mathrm{N}$ & $\mathrm{x}$ & $\mathrm{x}$ & & \\
\hline & Aerva-type lanata & $\mathrm{N}$ & $\mathrm{x}$ & $\mathrm{x}$ & & \\
\hline & Alternanthera & $\mathrm{N}$ & $\mathrm{x}$ & $\mathrm{x}$ & & \\
\hline & Amaranthaceae undiff. & I & $\mathrm{x}$ & $\mathrm{x}$ & & \\
\hline & Celosia-type trigyna & $\mathrm{N}$ & $\mathrm{x}$ & $\mathrm{x}$ & & \\
\hline & Chenopodium-type & $\mathrm{N}$ & $\mathrm{x}$ & $\mathrm{x}$ & $\mathrm{x}$ & \\
\hline & Gomphrena & $\mathrm{N}$ & $\mathrm{x}$ & $\mathrm{x}$ & & \\
\hline & Suaeda & I & $\mathrm{x}$ & $\mathrm{x}$ & & \\
\hline \multirow[t]{2}{*}{ ANACARDIACEAE } & Anacardiaceae undiff. & $\mathrm{A}$ & & & $\mathrm{x}$ & $\mathrm{x}$ \\
\hline & Lannea-type & A & & $\mathrm{x}$ & $\mathrm{x}$ & $\mathrm{x}$ \\
\hline APIACEAE & Apiaceae undiff. & I & & $\mathrm{x}$ & $\mathrm{x}$ & \\
\hline
\end{tabular}


Table 1. Continued.

\begin{tabular}{|c|c|c|c|c|c|c|}
\hline Family & Taxon & $\begin{array}{l}\text { Life } \\
\text { form }\end{array}$ & SH & SL & SU & GU \\
\hline \multirow[t]{2}{*}{ APOCYNACEAE } & Apocynaceae undiff. & $\mathrm{I}$ & $\mathrm{x}$ & $\mathrm{x}$ & $\mathrm{x}$ & \\
\hline & Tabernaemontana & $\mathrm{AL}$ & & & $\mathrm{x}$ & $\mathrm{x}$ \\
\hline \multirow[t]{2}{*}{ ARECACEAE } & Elaeis guineensis & PA & & & & $\mathrm{x}$ \\
\hline & Phoenix reclinata-type & PA & $\mathrm{x}$ & $\mathrm{x}$ & $\mathrm{x}$ & $\mathrm{x}$ \\
\hline ASCLEPIADACEAE & Gymnema & $\mathrm{AL}$ & $\mathrm{x}$ & & & \\
\hline \multirow[t]{3}{*}{ ASTERACEAE } & Asteraceae undiff. & I & $\mathrm{x}$ & $\mathrm{x}$ & $\mathrm{x}$ & \\
\hline & Centaurea-type perrottetii & $\mathrm{N}$ & $\mathrm{x}$ & $\mathrm{x}$ & & \\
\hline & Cichorieae undiff. & I & $\mathrm{x}$ & $\mathrm{x}$ & $\mathrm{x}$ & \\
\hline BOMBACACEAE & Adansonia digitata & A & & & $\mathrm{x}$ & $\mathrm{x}$ \\
\hline BURSERACEAE & Commiphora africana-type & A & & $\mathrm{x}$ & $\mathrm{x}$ & \\
\hline CAESALPINIACEAE & Detarium senegalense & $\mathrm{A}$ & & & $\mathrm{x}$ & $\mathrm{x}$ \\
\hline \multirow[t]{2}{*}{ CAPPARACEAE } & Capparis fascicularis-type & $\mathrm{AL}$ & & $\mathrm{x}$ & $\mathrm{x}$ & \\
\hline & Cleome-type gynandra & $\mathrm{N}$ & $\mathrm{x}$ & $\mathrm{x}$ & & \\
\hline \multirow[t]{4}{*}{ CARYOPHYLLACEAE } & Caryophyllaceae undiff. & I & $\mathrm{x}$ & $\mathrm{x}$ & & \\
\hline & Cerastium-type & $\mathrm{N}$ & $\mathrm{x}$ & $\mathrm{x}$ & & \\
\hline & Polycarpaea-type & $\mathrm{N}$ & $\mathrm{x}$ & $\mathrm{x}$ & $\mathrm{x}$ & \\
\hline & Polycarpon-type & $\mathrm{N}$ & $\mathrm{x}$ & $\mathrm{x}$ & $\mathrm{x}$ & $\mathrm{x}$ \\
\hline CASUARINACEAE & Casuarina equisetifolia-type & A & & & & \\
\hline \multirow[t]{2}{*}{ CELASTRACEAE } & Celastraceae undiff. & $\mathrm{AL}$ & $\mathrm{x}$ & $\mathrm{x}$ & $\mathrm{x}$ & \\
\hline & Salacia & AL & & & $\mathrm{x}$ & $\mathrm{x}$ \\
\hline CHRYSOBALANACEAE & Chrysobalanus/Parinari & A & & & $\mathrm{x}$ & $\mathrm{x}$ \\
\hline COMBRETACEAE & Combretaceae undiff. & $\mathrm{A}$ & & $\mathrm{x}$ & $\mathrm{x}$ & $\mathrm{x}$ \\
\hline \multirow[t]{2}{*}{ COMMELINACEAE } & Commelina-type benghalensis & $\mathrm{N}$ & & $\mathrm{x}$ & $\mathrm{x}$ & $\mathrm{x}$ \\
\hline & Commelina-type forskalaei & $\mathrm{N}$ & $\mathrm{x}$ & $\mathrm{x}$ & & \\
\hline \multirow[t]{2}{*}{ CONVOLVULACEAE } & Convolvulus-type & $\mathrm{N}$ & $\mathrm{x}$ & $\mathrm{x}$ & $\mathrm{x}$ & \\
\hline & Ipomoea-type & I & $\mathrm{x}$ & $\mathrm{x}$ & $\mathrm{x}$ & \\
\hline CYPERACEAE & Cyperaceae undiff. & $\mathrm{Nq}$ & & & & \\
\hline DILLENIACEAE & Tetracera & $\mathrm{AL}$ & & & $\mathrm{x}$ & $\mathrm{x}$ \\
\hline \multirow[t]{2}{*}{ EBENACEAE } & Diospyros & A & & & $\mathrm{x}$ & $\mathrm{x}$ \\
\hline & Ebenaceae undiff. & A & & & & \\
\hline EPHEDRACEAE & Ephedra & $\mathrm{AL}$ & $\mathrm{x}$ & & & \\
\hline
\end{tabular}


Table 1. Continued.

\begin{tabular}{|c|c|c|c|c|c|c|}
\hline Family & Taxon & $\begin{array}{l}\text { Life } \\
\text { form }\end{array}$ & $\mathrm{SH}$ & SL & $\mathrm{SU}$ & $\mathrm{GU}$ \\
\hline \multirow[t]{10}{*}{ EUPHORBIACEAE } & Acalypha & I & & & $\mathrm{x}$ & $\mathrm{x}$ \\
\hline & Alchornea & $\mathrm{A}$ & & & $\mathrm{x}$ & $\mathrm{x}$ \\
\hline & Anthostema-type & A & & & & $\mathrm{x}$ \\
\hline & Antidesma-type & A & & & $\mathrm{x}$ & $\mathrm{x}$ \\
\hline & Bridelia-type & $\mathrm{A}$ & & & $\mathrm{x}$ & $\mathrm{x}$ \\
\hline & Erythrococca-type & A & & & $\mathrm{x}$ & $\mathrm{x}$ \\
\hline & Hymenocardia & A & & $\mathrm{x}$ & $\mathrm{x}$ & $\mathrm{x}$ \\
\hline & Macaranga-type & A & & & $\mathrm{x}$ & $\mathrm{x}$ \\
\hline & Mallotus-type & A & & & $\mathrm{x}$ & $\mathrm{x}$ \\
\hline & Uapaca & $\mathrm{A}$ & & & $\mathrm{x}$ & $\mathrm{x}$ \\
\hline FABACEAE & Aeschynomene & I & & & $\mathrm{x}$ & $\mathrm{x}$ \\
\hline HALORRHAGACEAE & Laurembergia tetrandra & $\mathrm{Nq}$ & & & & \\
\hline LAMIACEAE & Basilicum-type polystachyon & $\mathrm{N}$ & & & $\mathrm{x}$ & \\
\hline LORANTHACEAE & Tapinanthus-type & $\mathrm{L}$ & & $\mathrm{x}$ & $\mathrm{x}$ & $\mathrm{x}$ \\
\hline MALVACEAE & Hibiscus & I & $\mathrm{x}$ & $\mathrm{x}$ & $\mathrm{x}$ & \\
\hline MELIACEAE & Khaya-type senegalensis & A & & & & $\mathrm{x}$ \\
\hline \multirow[t]{3}{*}{ MENISPERMACEAE } & Cissampelos-type & $\mathrm{AL}$ & & & $\mathrm{x}$ & $\mathrm{x}$ \\
\hline & Cocculus & $\mathrm{L}$ & $\mathrm{x}$ & $\mathrm{x}$ & $\mathrm{x}$ & \\
\hline & Tinospora bakis & $\mathrm{L}$ & $\mathrm{x}$ & $\mathrm{x}$ & $\mathrm{x}$ & \\
\hline \multirow[t]{2}{*}{ MIMOSACEAE } & Acacia & $\mathrm{AL}$ & $\mathrm{x}$ & $\mathrm{x}$ & $\mathrm{x}$ & \\
\hline & Prosopis-type africana & A & & $\mathrm{x}$ & $\mathrm{x}$ & $\mathrm{x}$ \\
\hline \multirow[t]{3}{*}{ MORACEAE } & Ficus & A & & $\mathrm{x}$ & $\mathrm{x}$ & \\
\hline & Musanga-type & A & & $\mathrm{x}$ & $\mathrm{x}$ & $\mathrm{x}$ \\
\hline & Myrianthus-type & A & & & & $\mathrm{x}$ \\
\hline MYRTACEAE & Syzygium-type guineense & A & & & $\mathrm{x}$ & $\mathrm{x}$ \\
\hline NYMPHAEACEAE & Nymphaea & $\mathrm{Nq}$ & & & & \\
\hline OCHNACEAE & Lophira & A & & & $\mathrm{x}$ & $\mathrm{x}$ \\
\hline ONAGRACEAE & Ludwigia-type ascendens & $\mathrm{Nq}$ & & & & \\
\hline POACEAE & Poaceae undiff. & $\mathrm{N}$ & $\mathrm{x}$ & $\mathrm{x}$ & $\mathrm{x}$ & $\mathrm{x}$ \\
\hline POLYGALACEAE & Polygala-type & I & $\mathrm{x}$ & $\mathrm{x}$ & $\mathrm{x}$ & \\
\hline POLYGONACEAE & Polygonum senegalense & $\mathrm{Nq}$ & & & & \\
\hline POTAMOGETONACEAE & Potamogeton & $\mathrm{Nq}$ & & & & \\
\hline
\end{tabular}


Table 1. Continued.

\begin{tabular}{|c|c|c|c|c|c|c|}
\hline Family & Taxon & $\begin{array}{l}\text { Life } \\
\text { form }\end{array}$ & $\mathrm{SH}$ & SL & SU & $\mathrm{GU}$ \\
\hline RANUNCULACEAE & Clematis-type & $\mathrm{AL}$ & $\mathrm{x}$ & $\mathrm{x}$ & $\mathrm{x}$ & \\
\hline \multirow[t]{9}{*}{ RUBIACEAE } & Leptactina & A & & & & $\mathrm{x}$ \\
\hline & Hymenodictyon-type & A & & & $\mathrm{x}$ & $\mathrm{x}$ \\
\hline & Ixora-type & A & & & $\mathrm{x}$ & $\mathrm{x}$ \\
\hline & Mitracarpus villosus & $\mathrm{N}$ & & $\mathrm{x}$ & $\mathrm{x}$ & \\
\hline & Mitragyna-type inermis & A & & $\mathrm{x}$ & $\mathrm{x}$ & $\mathrm{x}$ \\
\hline & Morelia senegalensis & A & & $\mathrm{x}$ & $\mathrm{x}$ & $\mathrm{x}$ \\
\hline & Pavetta & $\mathrm{AL}$ & & & $\mathrm{x}$ & $\mathrm{x}$ \\
\hline & Rubiaceae undiff. & $\mathrm{I}$ & $\mathrm{x}$ & $\mathrm{x}$ & $\mathrm{x}$ & $\mathrm{x}$ \\
\hline & Spermacoce-type radiata & $\mathrm{N}$ & & $\mathrm{x}$ & $\mathrm{x}$ & \\
\hline RUTACEAE & Zanthoxylum-type zanthoxyloides & $\mathrm{A}$ & & & $\mathrm{x}$ & $\mathrm{x}$ \\
\hline SALVADORACEAE & Salvadora persica-type & A & $\mathrm{x}$ & $\mathrm{x}$ & & \\
\hline \multirow[t]{3}{*}{ SAPINDACEAE } & Allophylus & $\mathrm{AL}$ & & $\mathrm{x}$ & $\mathrm{x}$ & $\mathrm{x}$ \\
\hline & Paullinia pinnata & $\mathrm{L}$ & & & $\mathrm{x}$ & $\mathrm{x}$ \\
\hline & Sapindaceae undiff. & $\mathrm{AL}$ & & $\mathrm{x}$ & $\mathrm{x}$ & $\mathrm{x}$ \\
\hline \multirow[t]{2}{*}{ SAPOTACEAE } & Sapotaceae undiff. & $\mathrm{AL}$ & & $\mathrm{x}$ & $\mathrm{x}$ & $\mathrm{x}$ \\
\hline & Vitellaria-type paradoxa & A & & & & $\mathrm{x}$ \\
\hline SOLANACEAE & Solanum-type & I & $\mathrm{x}$ & $\mathrm{x}$ & $\mathrm{x}$ & \\
\hline STERCULIACEAE & Dombeya-type & $\mathrm{A}$ & & & $\mathrm{x}$ & $\mathrm{x}$ \\
\hline TAMARICACEAE & Tamarix & A & $\mathrm{x}$ & $\mathrm{x}$ & & \\
\hline TILIACEAE & Triumfetta-type & I & & $\mathrm{x}$ & $\mathrm{x}$ & \\
\hline TYPHACEAE & Typha & $\mathrm{Nq}$ & & & & \\
\hline ULMACEAE & Celtis & A & & $\mathrm{x}$ & $\mathrm{x}$ & $\mathrm{x}$ \\
\hline ZYGOPHYLLACEAE & Tribulus & $\mathrm{N}$ & $\mathrm{x}$ & $\mathrm{x}$ & & \\
\hline
\end{tabular}

Data are presented as percentages and influx values (number of grains $/ \mathrm{cm}^{2} /$ year) and diagrams are drawn using Tilia and CONISS (Grimm 1991). Pollen percentages were calculated against a sum excluding aquatics and ferns, the percentages of which were calculated separately against a sum including all the pollen grains and fern spores counted. Algae and fungi percentages were calculated against the sum of NPP. Correspondence statistical analyses (CA) were performed on the raw pollen counts using the Package 'Rcmdr/FactoMinR' (Husson et al. 2020).

An age model was derived from three Accelerator Mass Spectrometry (AMS) radiocarbon dates and an additional control point given by the first occurrence of Casuarina equisetifolia pollen grains, the parent trees of which were planted in 1948 along the coast (Ndiaye et al. 1993), using the Bacon age-depth modeling (Blaauw and Christen 2011) from calibrated ${ }^{14} \mathrm{C}$ ages (Reimer et al. 2013) (Table 2). 
Table 2. Mboro-Baobab ages. Radiocarbon dating $(99.5 \mathrm{~cm}, 299.5 \mathrm{~cm}$, and $399.5 \mathrm{~cm})$ was conducted at UMS-ARTEMIS AMS Facilities (France). At $30.5 \mathrm{~cm}$ downcore, the first appearance of Casuarina equisetifolia pollen grains provide a date of $1948 \mathrm{CE}$. The age of the surface is that of coring (from Lézine et al. 2019).

\begin{tabular}{lllllll}
\hline $\begin{array}{l}\text { Lab. } \\
\text { number }\end{array}$ & $\begin{array}{l}\text { Mean } \\
\text { depth }(\mathrm{cm})\end{array}$ & Nature & $\begin{array}{l}\text { Radiocarbon } \\
\text { Age BP }\end{array}$ & Error & $\delta^{13} \mathrm{C}$ & $\begin{array}{l}\text { Age cal } \\
\text { yr BP }\end{array}$ \\
\hline & 0 & $\begin{array}{l}\text { Date of coring } \\
\text { Casuarina pollen }\end{array}$ & & & & -66 \\
49827 & 30.5 & Bulk sediment & 580 & 30 & $-22.40 \%$ o & 604 \\
49828 & 299.5 & Bulk sediment & 3265 & 30 & $-28.60 \%$ & 3496 \\
49829 & 399.5 & Bulk sediment & 3865 & 30 & $-29.10 \%$ o & 4298 \\
\hline
\end{tabular}

\subsection{POLLEN DIAGRAM}

Based on the variations in percentages of the main pollen taxa and NPP types, four zones corresponding to the main phases of landscape evolution over the last 4300 years can be distinguished. Zones 3 and 4 were presented in detail in Lézine et al. (2019, Figure 2).

\subsubsection{Zone 1A: 4300 - 3700 cal yr BP}

Guinean tree taxa such as Mallotus (3\%), Zanthoxylum (2.4\%), Uapaca (2.5\%), Alchornea (15\%) and Macaranga (11\%) characterized this zone. Lakeshore populations are reduced with Typha percentages less than $1 \%$.

Among the NPPs, Pediastrum and Coelastrum are largely dominant with percentages that can reach values above $80 \%$ for Pediastrum and $30 \%$ for Coelastrum.

\subsubsection{Zone 1B: 3700 - 3050 cal yr BP}

There is little change from the previous zone. However, the forest taxa listed above decreased significantly (e.g. Uapaca (0.3\%)). Other tree taxa such as Lannea (1.2\%) and Mitragyna (1.2\%) increased, along with taxa from lakeshore populations, Syzygium (7.2\%) and Elaeis (1.2\%). Upland herbaceous taxa, such as Amaranthaceae and Aerva, which were occasionally present in zone 1A, also increased. However, their percentages remained low (less than 1.5\%).

Among the NPPs, this zone is characterized by the rapid development of Tetraedron, which reached up to $80 \%$ reflecting the onset of the lake level lowering.

\subsubsection{Zone 2A: 3050 - 1600 cal yr BP}

This zone is characterized by the sharp increase in Typha percentages (15\%) and the more gradual increase of Cyperaceae (22.8\%) showing the development of reed swamp populations around the lake. Among the trees, Mallotus or Uapaca gradually decrease to less than $0.5 \%$, whereas Alchornea increased (16.5\%). Dry herbaceous taxa, such as Mitracarpus and Spermacoce, already present previously, increased with percentages up to $4 \%$.

NPP are characterized by the progressive increase in the percentages of Botrycoccus, $($ maximum $=17 \%)$.

\subsubsection{Zone 2B: $1600-700$ cal yr BP}

Cyperaceae (23\%) then Elaeis $(2.6 \%)$ increased in this zone. Some tree taxa of Guinean affinity (Mallotus, Anthostema, Zanthoxylum, Celtis) or wetlands decreased or even disappeared 


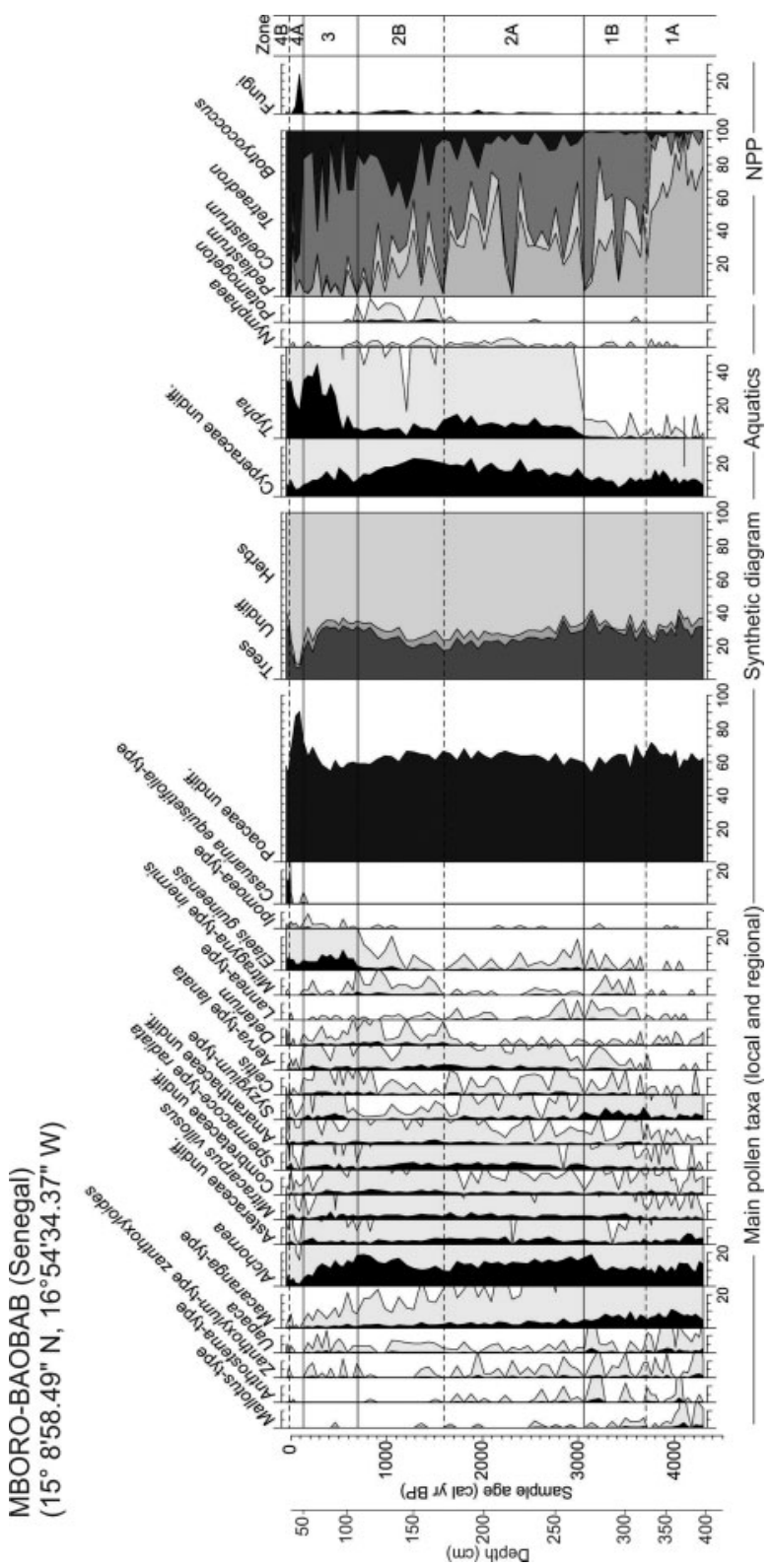

Figure 2. Figure showing from left to right, a simplified diagram of pollen percentages for Mboro-Baobab (Senegal). Black shading shows selected taxa. Light-gray shading shows the same results, multiplied by 10 for highlighting. On the right, the main NPP (Algae and Fungi) are shown.

almost completely, while others were stable (Alchornea 19\%) or even increased (Detarium 2.1\%, Mitragyna 1.6\%). Typha percentages decreased significantly (5\%) while another aquatic plant, Potamogeton (1.9\%), appeared.

Among the NPPs, Tetraedron and Botryococcus continued to increase until reaching $85 \%$ and $47 \%$, respectively. 


\subsubsection{Zone 3: 700 - 129 cal yr BP}

Alchornea and Elaeis dominated this zone though following an opposite trend. Elaeis reached its highest value (12\%) while Alchornea decreased steadily (minimum at $4.5 \%$ ). Syzygium remained well represented (2\%). Among read swamp populations, Typha increased remarkably, up to $35 \%$ and Cyperaceae decreased (7\%). NPPs were dominated by Tetraedron (up to 90\%) and Botryococcus (up to $60 \%$ ).

\subsubsection{Zone 4A: 129 - 14 cal yr BP}

This zone is characterized by the massive increase in Poaceae $(90 \%)$ and the correlative decrease in Typha (17\%). The percentages of Elaeis remained at the level reached in the previous area $(7 \%)$. Botryococcus almost exclusively dominated the algae assemblage. This zone is also characterized by the noticeable presence of fungi.

\subsubsection{Zone 4B: 14 cal yr BP - Modern}

This zone differs from the previous one by the appearance of Casuarina equisetifolia, which reaches up to $16 \%$. Poaceae decreased to $55 \%$, in contrast to Typha, which increased to values above $30 \%$. Botryococcus totally dominated the assemblages of algae.

\subsection{ENVIRONMENTAL RECONSTRUCTION AND DISCUSSION}

\subsubsection{The decline in tropical humid plant taxa}

Figure 3 is the graphical representation of a correspondence analysis using the microfossil assemblages for the environmental evolution of the Mboro-Baobab area. Three groups of taxa emerge from this analysis. The first is dominated by tropical humid (Guinean) tree taxa (e.g. Dictyandra, Macaranga, Mallotus, Syzygium, Uapaca), the second group is a mixture of taxa from trees and herbs of drier, Sudanian, phytogeographical affinity or having a wide spatial distribution (e.g. Alchornea, Asteraceae, Celtis, Mitracarpus). The third group is dominated by herbs found today in dry places in the Sahara and Sahel (e.g. Aerva lanata, Tribulus, Amaranthaceae). Only few trees are found in this group (e.g. Acacia, Adansonia digitata).

The most striking result of the analysis of these groups is the major environmental change revealed at $3200 \mathrm{cal}$ yr BP (Figure 4A). The most humid tree taxa (group 1) which dominated earlier in the record, and particularly around 3875 cal yr BP (Figure 4B), dramatically declined in favor of drier plant taxa (group 2). This decline continued into the late Holocene in two main stages respectively around 2500 and $1300 \mathrm{cal} \mathrm{yr} \mathrm{BP.} \mathrm{Contrasting} \mathrm{with} \mathrm{this} \mathrm{step-like} \mathrm{evolution} \mathrm{of}$ forest diversity, the regional, dry elements (group 3) exhibit a slow increasing trend starting from $3700 \mathrm{cal}$ yr BP and peaking around 1600-1300 cal yr BP.

\subsubsection{Changes in the hydrological regime}

The 3200 cal yr BP event closely matches a major change in the hydrological regime (Figure 4C): changes in the algal community show that the lowering of the water level was initiated as soon as $3750 \mathrm{cal} \mathrm{yr} \mathrm{BP} \mathrm{(cf.} \mathrm{expansion} \mathrm{of} \mathrm{Tetraedron,} \mathrm{Figure} \mathrm{2).} \mathrm{At} 3200 \mathrm{cal} \mathrm{yr} \mathrm{BP,} \mathrm{the} \mathrm{development}$ of the oligotrophic algae Botryococcus (Figure 2 and 4C) mark the reduction in nutrient supply due to increasingly dry conditions, which culminated during the last millennium. The strong decline in the freshwater algae Pediastrum and Coelastrum, followed by the development of Typha populations, confirms this major change in the hydrological regime and the lowering of the lake level. 


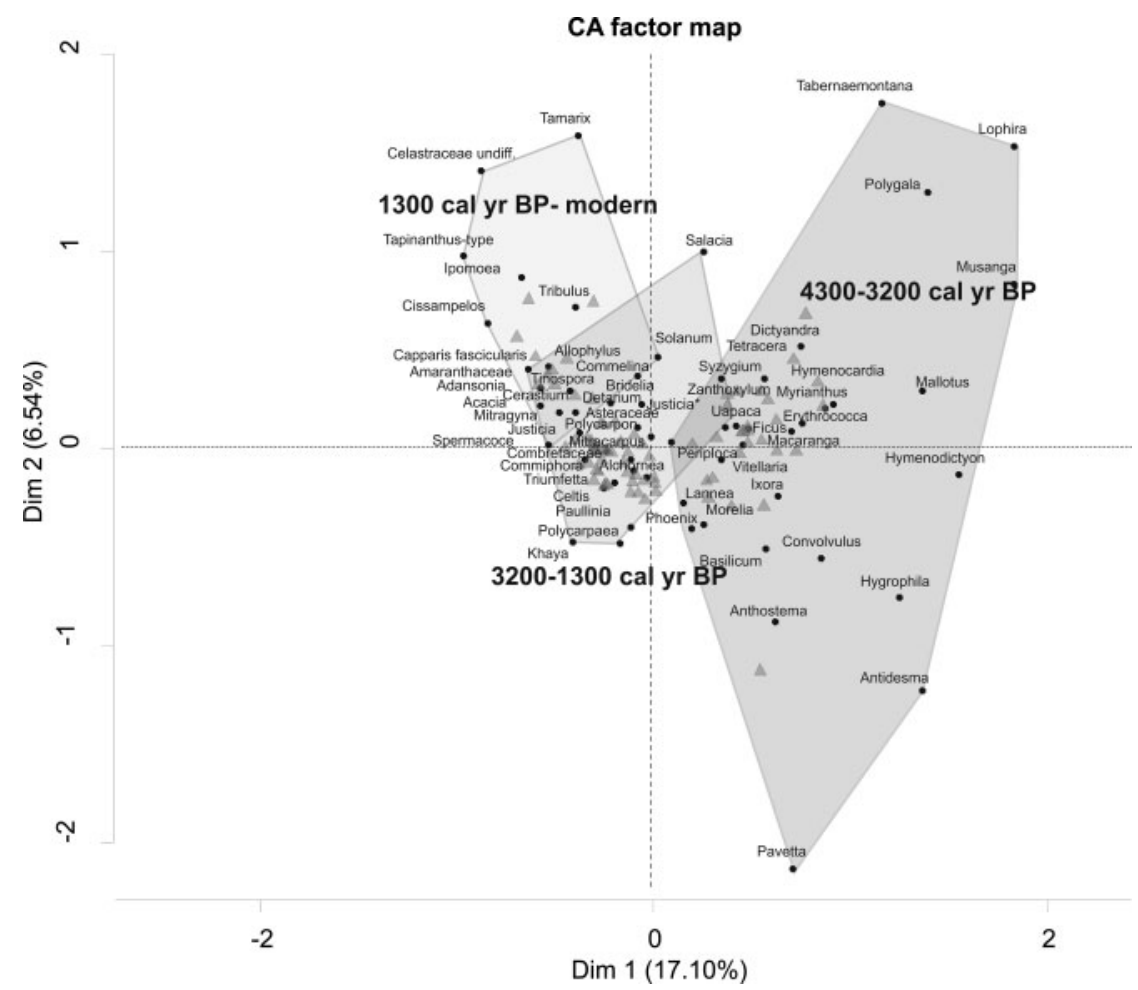

Figure 3. Correspondence analyses on the Mboro-Baobab pollen counts allowing distinction of tree main groups of taxa according to a decreasing humidity gradient. These groups define three periods (in bold).

\subsubsection{Timing of the end of the AHP in the Sahel}

Earlier work by Lézine $(1988,1989)$ in the Niayes suggested the sudden disappearance of the gallery forests around 2500 cal yr BP as illustrated at Diogo, only a few kilometers north of Mboro (Figure 1A). Diogo illustrates the magnitude of this environmental crisis by showing the drop in the water level allowing for the development of a Cyperaceae swamp contemporaneous with the collapse of most of the trees, which established during the AHP (Figure 5). Only swamp forest (Syzygium) and pioneer (Alchornea) trees were able to persist in a context of increased dry conditions (Braconnot et al. 2019).

Our Mboro-Baobab record does not show such an abrupt shift from a humid to a dry environment. The tree cover (AP\%, cf. Lézine et al., this issue) was never highly developed, probably due to the distal position of the site with respect to the core of the Niaye groundwater system (Diogo) (Putallaz 1962) and seems to have only slightly varied over the last 4300 years (Figure 2). Forest composition however strongly changed. Guinean taxa underwent a clear phase of expansion centered at $3875 \mathrm{cal} \mathrm{yr} \mathrm{BP.} \mathrm{A} \mathrm{similar} \mathrm{phase} \mathrm{of} \mathrm{development} \mathrm{of} \mathrm{tropical} \mathrm{trees} \mathrm{is} \mathrm{seen}$ at Jikariya (Waller et al. 2007) in the Manga grasslands of northern Nigeria between 3800 and $3500 \mathrm{cal} \mathrm{yr}$ BP that points to the regional character of this short phase of forest recovery. At Mboro-Baobab, this forest phase ended rapidly with steppic conditions increasing as soon as $3750 \mathrm{cal}$ yr BP. Interestingly, this increase in aridity did not have an immediate effect on the composition of the forest gallery but probably only on its density. It is only at $3200 \mathrm{cal}$ yr BP that the replacement of the wettest forest elements by forest taxa more adapted to drier climatic 


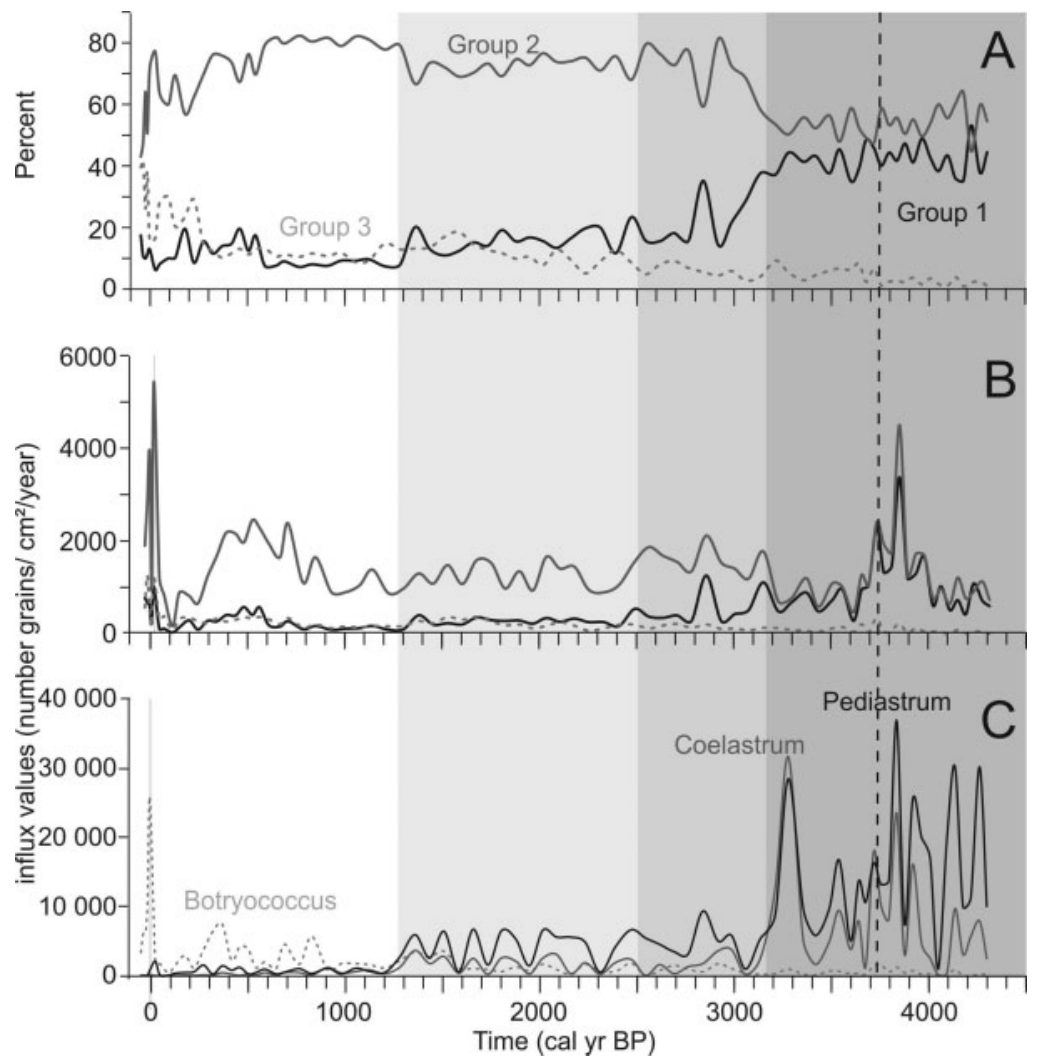

Figure 4. Summary of the evolution of the environment at Mboro-Baobab over the last 4300 years. (A) Percentages of the three groups of pollen taxa revealed by the CA statistical analysis; (B) influx values of these groups; (C) influx values of the algae Pediatrum, Coelastrum and Botryococcus. The gray bars (from dark to light) show the progressive decline of the most humid elements. The dotted line shows the onset of dryness in a still humid context. Note that curves are superimposed and not cumulative.

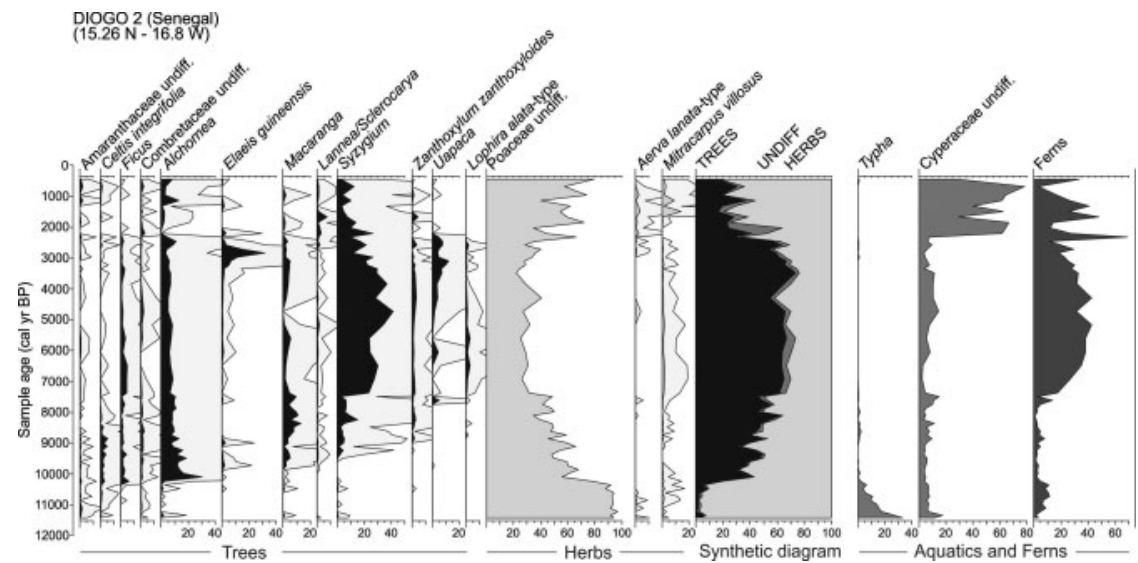

Figure 5. Percentage pollen diagram of main taxa from Diogo in the Niaye area of Senegal (Lézine 1988). 
conditions occurred. This replacement was not as abrupt as at Diogo but its amplitude was not negligible as shown by the decrease in percentages of group 1 by about $10 \%$ (Figure 4A). Taking into account the chronological uncertainties between sites, our Mboro-Baobab record closely fits with that of Jikaryia, which dates the decline of tropical humid trees at $3150 \mathrm{cal}$ yr BP.

\subsection{CONCLUSION}

As already noted by Waller et al. (2007), significant differences in the timing and amplitude of similar events may occur in pollen records from the same region. The size of the sites and their location with respect to groundwater availability are among the parameters that can influence the local response of plants to climate change in terms of amplitude and timing. Compared to the other Niaye sites (Lézine 1988) Mboro-Baobab contains the most complete and detailed record of the end of the AHP. Despite its location on the edge of the wettest zone of the Niayes region, where the forest gallery was only poorly developed, it has undergone profound environmental changes allowing distinction of the successive phases in the establishment of the modern landscape. The drying of the Mboro-Baobab landscape was gradual, starting from $3750 \mathrm{cal}$ yr BP then culminating at $1300 \mathrm{cal}$ yr BP. In contrast, a major shift in the lake system and the forest diversity occurred at $3200 \mathrm{cal}$ yr BP, marked by the lowering of the water level and the sharp decline of the tropical humid forest elements. The species turnover initiated at that time continued up to $2500 \mathrm{cal}$ yr BP. Our results are consistent with those obtained in the central Sahel, which place the end of AHP between 3300 and $3150 \mathrm{cal} \mathrm{yr}$ BP depending on the site (Salzmann and Waller 1998; Waller et al. 2007). According to our study, the end of AHP (i.e. the retreat of the most humid elements from the gallery forests of the Niayes region) lasted about 700 years between 3200 and $2500 \mathrm{cal} \mathrm{yr} \mathrm{BP.} \mathrm{The} \mathrm{duration} \mathrm{of} \mathrm{this} \mathrm{transition} \mathrm{period} \mathrm{was} \mathrm{likely} \mathrm{favored} \mathrm{by} \mathrm{the} \mathrm{presence}$ of a water table close to the surface, which was able to maintain humid conditions for several centuries after the major event of $3200 \mathrm{cal}$ yr BP.

\section{ACKNOWLEDGEMENTS}

This work is an "ACCEDE" Belmont Forum contribution (18 BELM 0001 05). Thanks are due to the Institut de Recherche pour le Développement (IRD) and the UCAD Geological Department (Dakar, Senegal) for logistic support in the field and authorizations and to the ECLAIRS International Laboratory (Dakar) and the LOCEAN Laboratory (Paris) for funding. KL and AML are funded by CNRS, France.

\section{REFERENCES}

Association des Palynologues de Langue Française (APLF) 1974, Pollen et spores d'Afrique tropicale. Travaux et Documents de Géographie Tropicale 16 (Talence : CEGET).

Blaauw, M. and Christen, J. A., 2011, Flexible paleoclimate age-depth models using an autoregressive gamma process. Bayesian analysis, 6(3), pp. 457-474, 10.1214/ba/1339616472.

Bonnefille, R. and Riollet, G., 1980, Pollens des savanes d'Afrique orientale (Paris :CNRS).

Braconnot, P., Zhu, D., Marti, O. and Servonnat, J., 2019, Strengths and challenges for transient Mid- to Late Holocene simulations with dynamical vegetation. Climate of the Past, 15, pp. 997-1024, 10.5194/cp-15-997-2019.

De Menocal, P., Ortiz, J., Guilderson, T., Adkins, J., Sarnthein, M., Baker, L. and Yarusinsky, M., 2000, Abrupt onset and termination of the African Humid Period: Rapid climate 
responses to gradual insolation forcing. Quaternary Science Reviews, 19(1-5), pp. 347-361, 10.1016/S0277-3791(99)00081-5.

Faegri, K., Kaland, P. E. and Krzywinski, K., 1989, Textbook of pollen analysis, $4^{\text {th }}$ edition, (Chichester: John Wiley \& Sons Ltd).

Grimm, E. C., 1991, Tilia and Tiliagraph, (Springfield: Illinois State Museum).

Hély, C., Lézine, A.-M. and APD contributors, 2014, Holocene changes in African vegetation: tradeoff between climate and water availability. Climate of the Past, 10, pp. 681-686, 10.5194/cp-10-681-2014.

Husson, F., Josse, J. and Le, S., 2020, Package 'RcmdrPlugin. FactoMineR'. http://factominer. free.fr/graphs/RcmdrPlugin.html.

Jowsey, P. C., 1966, An improved peat sampler. New Phytologist, 65(2), pp. 245-248, 10.1111/ j.1469-8137.1966.tb06356.x.

Kröpelin, S., Verschuren, D., Lézine, A.-M., Eggermont, H., Cocquyt, C., Francus, P., Cazet, J. P., Fagot, M., Rumes, B., Russell, J. M., Darius, F., Conley, D. J., Schuster, M., von Suchodoletz, H. and Engstrom, D. R. 2008, Climate-driven ecosystem succession in the Sahara: the past 6000 years. Science, 320(5877), pp. 765-768, 10.1126/science. 1154913.

Kuper, R. and Kröpelin, S., 2006, Climate-controlled Holocene occupation in the Sahara: motor of Africa's evolution. Science, 313(5788), pp. 803-807, 10.1126/science.1130989.

Lécuyer, C., Lézine, A.-M., Fourel, F., Gasse, F., Sylvestre, F., Pailles, C., Grenier, C., Travi, Y. and Barral, A., 2016, In-Atei palaeolake documents past environmental changes in central Sahara at the time of the "Green Sahara": Charcoal, carbon isotope and diatom records. Palaeogeography, Palaeoclimatology, Palaeoecology, 441, pp. 834-844, 10.1016/j.palaeo. 2015.10.032.

Lézine, A.-M., 1988, Les variations de la couverture forestière mésophile d'Afrique occidentale au cours de l'Holocène. Comptes rendus de l'Académie des sciences, Série 2, 307(4), pp. 439-445.

Lézine, A.-M., 1989, Late Quaternary vegetation and climate of the Sahel. Quaternary Research, 32(3), pp. 317-334, 10.1016/0033-5894(89)90098-7.

Lézine, A.-M., Hély, C., Grenier, C., Braconnot, P. and Krinner, G., 2011, Sahara and Sahel vulnerability to climate changes, lessons from Holocene hydrological data. Quaternary Science Reviews, 30(21-22), pp. 3001-3012, 10.1016/j.quascirev.2011.07.006.

Lézine, A.-M., Holl, A.F.C., Lebamba, J., Vincens, A., Assi-Khaudjis, C., Février, L. and Sultan, E., 2013, Temporal relationship between Holocene human occupation and vegetation change along the northwestern margin of the Central African rainforest. Comptes Rendus Geoscience, 345(7-8), pp. 327-335, 10.1016/j.crte.2013.03.001.

Lézine, A.-M., Lemonnier, K. and Fofana, C.A.K., 2019, Sahel environmental variability during the last millennium: Insight from a pollen, charcoal and algae record from the Niayes area, Senegal. Review of Palaeobotany and Palynology, 271, 10.1016/j.revpalbo.2019.104103, p. 104103.

Maley, J., 1970, Contributions à l'étude du Bassin tchadien. Atlas de pollens du Tchad. Bulletin du Jardin botanique National de Belgique, 40(1), pp. 29-48, 10.2307/3667543.

Ndiaye, P., Mailly, D., Pineau, M. and Margolis, H.A., 1993, Growth and yield of Casuarina equisetifolia plantations on the coastal sand dunes of Senegal as a function of microtopography. Forest Ecology and Management, 56(1-4), pp. 13-28, 10.1016/0378-1127(93)90100-2.

Manning, K. and Timpson, A., 2014, The demographic response to Holocene climate change in the Sahara. Quaternary Science Reviews, 101, pp. 28-35, 10.1016/j.quascirev.2014.07.003.

ORSTOM, 1962, M Boro. Carte pédologique des Niayes, 1:10000. (Dakar: ORSTOM).

Putallaz, J., 1962, Hydrogéologie de la région des Niayes. Technical Report BRGM DAK 62 A 12.

Reimer, P. J., Bard, E., Bayliss, A., Beck, J. W., Blackwell, P. G., Ramsey, C. B., Buck, C.E., Cheng, H., Edwards, R.L., Friedrich, M., Grootes, P. M., Guilderson, T.P., Haflidason, H., 
Hajdas, I., Hatté, C., Heaton, T.J., Hoffman, D.L., Hogg, A.G., Hughen, K.A., Kaiser, K.F., Kromer, B., Manning, S.W., Niu, M., Reimer, R.W., Richards, D.A., Scott, E.M., Southon, J.R., Staff, R.A., Turney, C.S.M. and van der Plitch, J., 2013, IntCal13 and Marine13 radiocarbon age calibration curves 0-50,000 years cal yr BP. Radiocarbon, 55(4), pp. 1869-1887, 10.2458/ azu_js_rc.55.16947.

Salzmann, U. and Waller, M., 1998, The Holocene vegetational history of the Nigerian Sahel based on multiple pollen profiles. Review of Palaeobotany and Palynology, 100(1-2), pp. 39-72, 10.1016/S0034-6667(97)00053-5.

Trochain, J., 1940, Contribution à l'étude de la végétation du Sénégal (Paris: Larose).

Vincens, A., Lézine, A.-M., Buchet, G., Lewden, D. and Le Thomas, A., 2007, African pollen database inventory of tree and shrub pollen types. Review of Palaeobotany and Palynology, 145(1-2), pp. 135-141, 10.1016/j.revpalbo.2006.09.004.

Waller, M. P., Street-Perrott, F. A. and Wang, H., 2007, Holocene vegetation history of the Sahel: pollen, sedimentological and geochemical data from Jikariya Lake, north-eastern Nigeria. Journal of Biogeography, 34(9), pp. 1575-1590, 10.1111/j.1365-2699.2007.01721.x.

Watrin, J., Lézine, A.-M. and Hély, C., 2009, Plant migration and plant communities at the time of the "green Sahara". Comptes Rendus Geoscience, 341(8-9), pp. 656-670, 10.1016/j.crte.2009.06.007.

White, F., 1983, The vegetation of Africa (Paris: UNESCO).

Ybert, J.-P., 1979, Atlas de pollens de Côte d'Tvoire. Initiations-Documentations Techniques 40 (Paris: ORSTOM). 